\title{
THE ATTITUDES AND OPINIONS OF TEACHERS TO THEIR COMPETENCES
}

\author{
Dr. Suzana Nikodinovska Bancotovska, "Ss Cyril and Methodius" University \\ Faculty of Pedagogy "St Kliment Ohridski”, Skopje, Republic of Macedonia \\ E-mail: suzi.niko.bancot@gmail.com
}

Received: May, 17.2015.

Accepted: June, 04.2015.

Original Article

UDK 371.13

\begin{abstract}
The teaching profession is built upon the initial education on relevant pedagogical faculties, and further upgraded and improved through continuing education through various forms of professional development.

The competencies of the teacher for realization of educational activity represents the content and function of its professional obligations. Global taxonomy of teacher's competences are consisted of pedagogical competencies and professional competencies.

The pedagogical competence of the teacher has one main characteristic - it enables the organization and realization of educational process. The professional competences of the teacher, in fact, represent the competence and commitment to implement the teaching.

The subject of research in this paper is the professional competences of the teachers. The research is focused on the identification of the professional competencies of the teacher, with the possibility of extension and deepening of the established taxonomy with new competences.

The professional qualifications of teachers are closely related to the profile and characteristics of the educational system. Partial and global changes in educational systems have led to changes in competence of the teacher. In order to establish more successful future projection of the impact of teacher's competences on all school activities and arising results, the proposed changes will focus on: improving the quality of working conditions in primary schools - the basic requirements to equip with modern educational technology; changes in curriculum placement; greater efficiency of educational work; systematic assessment of the teacher, which will result in raising its position in society.
\end{abstract}

Keywords: Teacher, Competences, Profession, Teaching.

Corresponding Author

Dr. Suzana Nikodinovska Bancotovska, "Ss Cyril and Methodius" University, Faculty of Pedagogy "St Kliment Ohridski”, Skopje

E-mail: suzi.niko.bancot@gmail.com

\section{INTRODUCTION}

The teaching profession is built upon the initial education on relevant pedagogical faculties, and further upgraded and improved through continuing education through various forms of professional development.

In the creation of the teaching profession, the most important are the following points:

- acquiring of general knowledge;

- acquiring of pedagogical knowledge;

- penetration into the essence of pedagogical processes and phenomena - with special emphasis on training for teaching, educational and advisory activities; skills.

- acquiring professional knowledge and

The competences of the teacher for realization of educational activity represent the content and function of its professional obligations. These include all commitments and activities that teachers need to plan and implement. In fact, that's the global role of the teacher based on its skills (Gordon, T. 1998). In determining the competence of the teacher, it starts from the assumption what it should work, for what is competent; who and what types of activities should be implement.

This determination should be in accordance with the legal and regulatory framework, as well as the pedagogical requirements that are placed on the basis of modern pedagogical and didactic-methodical knowledge and needs (Банчотовска Н. С. 2008a).

The activities which should be realized by the teacher within his professional work, are considered as a system of processes, procedures and operations. They are planned and implemented in accordance with the set of goals in the curriculum, but with respect to the specific conditions and situations (Попоски, K. 1998). Those are such types of activities that are not strictly determined. They relate 
to the overall development of the educational system, not just the student.

Global taxonomy of competences of the teacher are consisted of pedagogical competences and professional competences.

This taxonomy is called global because the offered categories are further broken down into subcategories, and some of them even on more components (Bloom, B. 1981).

Pedagogical and professional competences of the teacher in the actual educational situation continuously complement and intertwine.

The pedagogical competence of the teacher has one main characteristic - it enables the organization and realization of educational process. In the formulation of pedagogical competencies crucial role has knowledge, skills and habits, which were acquired in the field of pedagogical sciences (didactics, methodologies of teaching subjects, school of pedagogy, methodology of research, the history of pedagogy, experimental pedagogy, comparative pedagogy, etc.).

The knowledge of these areas contribute to a proper understanding of the theory and practice of upbringing, education and instruction, introduction to the problems of educational work, understanding and acceptance of the possibilities and ways of educational impacts and their direction towards the global target but also towards individual goals of educational work. In addition, significant for pedagogical competences are psychology, sociology, philosophy, and cognitive knowledge and skills.

The professional competencies of the teacher, in fact, represent the competence and commitment for implementation of the teaching. The teacher approaching disclosure and explanation to students for scientific knowledge of the relevant subject, is didactic processing of a science. Students should gain a certain degree of knowledge of the subjects and the teacher is the one that will enable it (Банчотовска Н. С. 2008b).

\section{MATERIALS AND METHODS}

\section{Scope and purpose of the research}

Subject to research are the competences of the teachers. The taxonomy of competences was introduced by Банчотовска Н. С. 2008b. This paper will approach to the identification of competencies of teachers. The identification will be realized through examining the situation in the current educational reality.

The research is focused on the identification of the professional competences of the teacher, with the possibility of extension and deepening of the established taxonomy with new competences.

\section{Research and Hypotheses}

General hypothesis:

The professional and pedagogical competences of teachers are mostly identified based on the quality of initial education and less on vocational training.

Auxiliary hypotheses:

- In view of the implementation of the curriculum, teacher competences have been clearly understood and defined.

- Competences in relation to the treatment of the student, have already been modernized and redefined.

- Most teachers understand themselves as individuals enough competent for the activity they perform.

- The professional and pedagogical training across multiple forms and content can positively affect the promotion and realization of teacher competences. search

Methods, techniques and tools of re-

Research methods:

For this research the theoretical and analytical methodology was used.

Research Techniques:

- Inquiry

Research Instruments:

- Questionnaire

\section{Data processing:}

The data obtained in the research, is shown in tables. After sorting, the data is processed and displayed with the following statistical indicators: distribution of frequency (f) and percentage $(\%)$.

The population is comprised of all class teachers from primary schools in Macedonia. The sample was decided by random selection. The teachers examined are in lower classes of primary schools "Ljuben Lape" and "Gorgija Pulevski" from Skopje. 


\section{RESULTS AND DISCUSSIONS}

\author{
1. Analysis of the results of the inquiry \\ of the teachers
}

The interpretation of the results will be focued on requirements relevant to the scope of this paper. Answers of the questions of the closed type will be displayed in a table with a comment on the results. In the tables is entered data distribution frequency ( $\mathrm{f}$ ) and the percentages expression of the frequency $(\%)$. On the upper right corner of some part of chart is added the total number of respondents from two primary schools. In the bottom horizontal line of the chart is shown the total number of respondents who answered according to given alternation of the question.

Teachers from the primary school «Ljuben Lape» in the tables are marked with no. 1 and the teachers from the primary school «Gorgija Pulevski» with no. 2.

With these questions we open an opportunity to see some of the opinions of the teachers on specific issues relevant to the research that we are conducting. The analysis will allow us to find the comments, and then we will connect with other research results.

Analysis of the Question 1: What are your competences as a teacher?

The question is set to come to the realization that teachers know what are their competences, i.e. whether they are able to identify them. We are not entirely satisfied with the answers because we expect that teachers will be able to fully demonstrate their competencies. Namely, some teachers on this question gave generic answers; some of them partially answered the questions, indicating some of their competences. Butsome of the teachers stated more comprehensive display of competencies.

Some general answers are: «very small»; «Educational»; «Professional competence, pedagogical competence», «to devise and implement programs provided to the appropriate department, to bring innovation in the implementation and evaluation of the results «,» exclusively within the curriculum and implementation. Teachers who in detail described their competencies, gave the following answers: «My goal are the daily training, exchange of ideas and data, analysis of teaching», «teaching plan, realizing the teaching, the present school, participate in teams, committees - participation in seminars, trainings, projects», «to devise and implement programs provided to the appropriate department, to bring innovation in the implementation and make evaluation of the achieved results»; «education and upbringing of the students, planning and implementation of teaching regular, additional, extracurricular activities, assessing, monitoring, evaluation of students, working with children with special needs «,» responsible and reliable realization of teaching and educational process, including cooperation with parents and peers. «

From the analysis of the answers to this question we can conclude that teachers are familiar with their competence, however, it is precisely their classification. So the teachers properly and timely applied the competencies in the educational process, including any additional movements and activities in schools. gained:

Question 2 reads: Is competences

a) during the university study,

b) through professional development,

c) through the practice,

d) equally across all the above mentioned phases.

The results are presented in the Table «Way of acquiring competence»:

Table 1. «Way of acquiring competence»

\begin{tabular}{lccccccccccc}
\hline $\begin{array}{l}\text { Question } \\
\text { number 2 }\end{array}$ & a) & & b) & & c) & & d) & \multicolumn{2}{c}{ Total } \\
\hline Teachers & $\mathrm{f}$ & $\%$ & $\mathrm{f}$ & $\%$ & $\mathrm{f}$ & $\%$ & $\mathrm{f}$ & $\%$ & $\mathrm{f}$ & $\%$ \\
\hline School 1 & $/$ & $/$ & 4 & 2,66 & 2 & 13,33 & 9 & 60 & 15 & 100 \\
\hline School 2 & $/$ & $/$ & 3 & 20 & 1 & 6,66 & 11 & 73,33 & 15 & 100 \\
\hline Total & $/$ & $/$ & 7 & 23,33 & 3 & 10 & 10 & 20 & 30 & 100 \\
\hline
\end{tabular}

From the analysis of the responses to this question we can conclude that most of them $(66.66 \%)$ reported for the last offered answer - that all phases are equally important for the acquisition of competences. A small number of teachers think that the competences acquired solely through professional development $(23.33 \%)$, i.e. exclusively through practice $(20.00 \%)$.

Analysis of the Question 3: What do you think, which are the professional competencies relating to your competence and determination to implement teaching in terms of the content of the relevant school subjects?

This question is more concrete and the attention is focused on the teacher competencies related to the implementation of content on specific subjects. Answers relating to 
competence in terms of teaching subject and underpin their implementation, are: «planning and full implementation of the curriculum», «application of modern methods and techniques in all subjects», "cooperation with colleagues, parents, professional services, students»», "guidelines for working with the student outside of the school»,»vocational preparation, Bachelor of Engineering, seminars, training». »Furthermore, the following more specific answers: «my competencies are analysis and synthesis of teaching», «consideration of the material and its addition to professional literature», «digital competence, competence for native language, foreign language skills, interpersonal skills, mathematical skills...«, «individualized realization and differentiated teaching», «monitoring and evaluation of students «, «to plan an annual, topical, daily planning, to evaluate performance, to monitor the success and behavior of pupils, to submit reports and analysis to the Ministry of Education».

The answers are not specified in terms of the question, but give us some knowledge and relationships for further examination and analysis.

Analysis of the Question. 4: What do you mean which are the pedagogical competencies relating to your competence and determination to implement teaching in terms of the content of the teaching subjects?

The answers from the first aspect, are provided by the following considerations of teachers «as my responsibility is action in the classroom», "aapplication of modern pedagogical methods in the implementation of the educational process,» «educational advisory competence», «computer skills» «appropriate methodological approach for each educational content», «keeping pedagogical records, ediary, monitoring and evaluation of students, lectures from different areas». Related to the second aspect (subjective support), teachers provide the following answers: "Cooperation with pedagogical-psychological service with parents, cooperation with administrative services in local government, non-governmental and governmental organizations, cultural institutions,» «mentoring».

From the analysis of the questions under No. 3 and 4 we may conclude that for the teachers there is no sufficiently clear distinction between professional and pedagogical competencies. We assume that this is partial terminological barricade, and it does not affect the way the wealth and the realization of competences by teachers in primary schools.

\section{CONCLUSIONS}

The professional qualifications of teachers are closely related to the profile and characteristics of the educational system. Partial and global changes in educational systems lead to changes in competence of the teacher. Thus, competencies are supplemented, changed, transformed and perfected. Teacher, alternating itself, affects the competence and we can assume for individual adjustment of competences to the profile and to the style of the teacher.

Accordingly, we expect expansion and deepening of the taxonomy of competences of teachers, in parallel with developments in science and technology, resulting in changes in teaching (Howarth, G. A., 1999).

This paper is an attempt to present and highlight the importance of teachers' competences. Teacher's competences are especially important for the correct course of contemporary educational work that aims to continuous improvement and didactic-methodical enrichment with new and altered strategies of work adapted to the demands and the needs of the modern students.

The significance of teacher competence on the way to the course and the effects of their work are versatile. In fact, properly defined and applied competencies represent a solid foundation for the successful realization of educational goals and objectives. In order to establish more successful future projection of the impact of teacher competences on all the school activities and the arising results, we propose appropriate changes which will focus on:

- improving the quality of working conditions in primary schools - the basic requirements to equip with modern educational technology;

- changes in curriculum placement;

- greater efficiency of educational work; - systematic assessment of the teacher, which will result in raising its position in society.

Conflict of interests

Author declare no conflict of interest.

\section{REFERENCES}

Bloom, B. S., \& I... Furlan. (1981). Taksonomija ili klasifikacija obrazovnih $i$ odgojnih ciljeva: Kognitivno područje. Republički zavod za unapređivanje vaspitanja i obrazovanja.

Gordon, T., \& Lobodok-Štulić, I. (2003). Kako biti 
uspešan nastavnik. Kreativni centar.

Howarth, G. A. (1999). No-one forgets a good teacher. CHEMISTRY IN BRITAIN, 35(7), 18-19.

Банчотовска, Н. С. (2008a). Професионалните компетенции на наставниците. Академски печат, Скопје.

Банчотовска, Н. С. (2008b). Таксономија на професионалните компетенции на наставниците, Академски печат, Скопје.

Попоски, К. (1998). Успешен наставник. Скопје: Просветен работник. 
(IJCRSEE) International Journal of Cognitive Research in Science, Engineering and Education Vol. 3, No.1, 2015. 